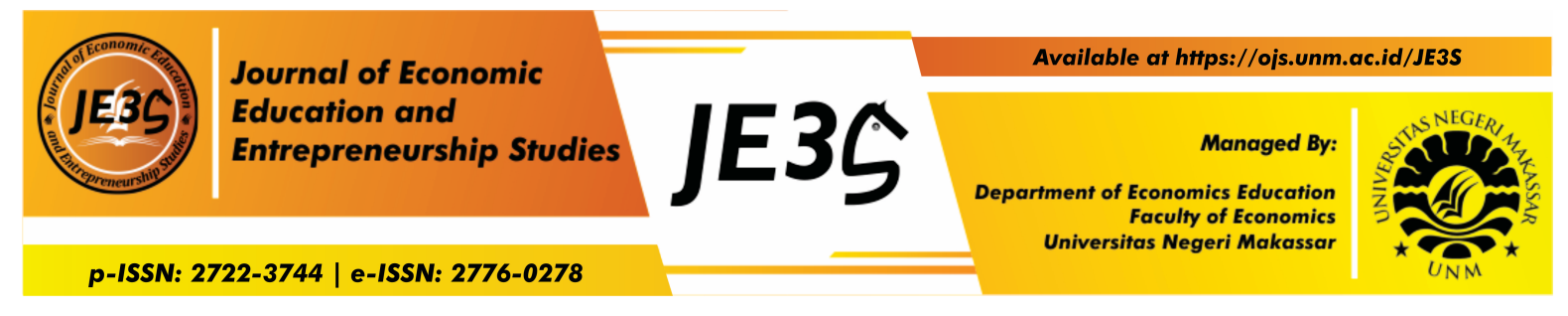

\title{
Pengaruh Program Flash Sale terhadap Perilaku Impulsive Buying Konsumen Marketplace
}

Dermawansyah Darwipat $^{1 *}$, Agus Syam ${ }^{2}$, Marhawati $^{3}$

${ }^{1,2,3}$ Fakultas Ekonomi Universitas Negeri Makassar

\begin{tabular}{l}
\hline Article History \\
\hline Received October 18, 2020 \\
Approved November 15, 2020 \\
Published December 30, 2020
\end{tabular}

$\frac{\text { Keywords }}{\text { Flash Sale, Impulsive Buying, }}$

Flash Sale, Impulsive Buying, marketplace

\begin{tabular}{l}
\hline \multicolumn{1}{c}{ JEL Classification } \\
\hline D12, M31, D91 \\
\hline \multicolumn{1}{c}{ How to Cite } \\
\hline Darwipat, D., Syam, A., \& Marhawati. \\
2020. Pengaruh Program Flash Sale \\
terhadap Perilaku Impulsive Buying \\
Konsumen Marketplace. Journal of \\
Economic Education and \\
Entrepreneurship Studies, 1(2), 58-64. \\
\hline
\end{tabular}

\begin{tabular}{l}
\hline Abstract \\
\hline This study aims to determine the effect of flash \\
sales on the impulsive buying behavior of \\
marketplace consumers in women. This research \\
is categorized as a quantitative descriptive study \\
with a simple regression approach. The \\
population in this study were 347 female students, \\
and a sample of 54 female students was obtained. \\
Data collection was carried out using \\
observation, documentation and questionnaire \\
techniques. The analysis technique used is simple \\
linear regression. The results of this study \\
indicate that the survey conducted on students of \\
the Department of Economics education resulted \\
in the conclusion that flash sales have a \\
significant effect on impulsive buying.
\end{tabular}

significant effect on impulsive buying.

\footnotetext{
*Dermawansyah Darwipat

Jl. Raya Pendidikan Kampus Universitas Negeri Makassar

Kota Makassar, Sulawesi Selatan,

e-mail: anchaasus22@gmail.com
}

(C) 2020 Universitas Negeri Makassar

\section{PENDAHULUAN}

Perdagangan elektronik e-commerce mencangkup proses pembelian, penjualan, transfer, atau pertukaran produk, layanan atau informasi melalui jaringan komputer, termasuk internet (Turban, 2012). E-commerce sering dianggap sederhana untuk merujuk kepada pembelian dan penjualan yang memakai internet (Chaffey, 2013). Terdapat beberapa e-commerce yang cukup terkenal di Indonesia seperti Marketplace, Bukalapak, Tokopedia, Blibli, Lazada, dan lain-lain.

Berdasarkan data e-commerce, menunjukkan bahwa Tokopedia menempati urutan pertama untuk pengunjung web bulanan yang yakni hingga 140.414.500 
pengunjung. Sementara, posisi kedua ditempati oleh Marketplace sebanyak 90.705.300 pengunjung dan poisi kesepuluh ditempati oleh Zalora dengan 5.218.300 pengunjung.

Ramainya pemain di dunia bisnis online membuat persaingan semakin ketat. Setelah diskon dan promo, biasa tidak lagi ampuh mendatangkan customer, kini para penjual online mengenalkan istilah baru dalam berbelanja murah yang disebut dengan flash sale. Flash sale adalah strategi dalam bisnis online untuk menjual barang secara eksklusif dengan harga yang jauh lebih murah dari aslinya, dan tentunya dalam waktu yang sangat terbatas. Tujuan strategi ini adalah meningkatkan penjualan, mengundang traffic ke toko online, dan juga bisa meningkatkan brand awareness agar semakin dikenal oleh publik. Adanya program flash sale ini mampu memicu impulse seseorang untuk membeli produk yang diinginkannya. Apalagi marketplace juga menyediakan beberapa promosi penjualan seperti gratis dalam program flash sale. Dengan promosi tersebut, seseorang yang memiliki jiwa belanja yang kuat pasti akan melakukan pembelian secara tiba-tiba tanpa memiliki perencaan sebelumnya. Konsumen merasa adanya stimulus yang kuat dan mempengaruhi mereka untuk melakukan pembelian secepatnya.

Spontanitas konsumen dalam berbelanja sangatlah wajar sebagai bentuk pemenuhan kebutuhan. Terjadinya spontanitas ketika seseorang melihat suatu barang yang diinginkan dan sedang ada diskon (potongan harga), tanpa berfikir panjang seseorang akan melakukan pembelian barang walaupun ada risiko yang harus ditanggung. Perilaku tersebut biasanya disebut dengan pembelian impulsif (impulse buying). Impulse buying merupakan perilaku atau tindakan konsumen yang impulsif atau tanpa rencana untuk dapat berpikir panjang mengenai produk/barang yang akan dibelinya secara cepat tanpa memikirkan akibat (Peck \& Childers, 2006)

Perilaku pembelian impulsif sering terjadi karena motivasi belanja hedonis (Park et al., 2006), di mana konsumen cenderung berperilaku impulsif ketika mereka memiliki motivasi hedonis seperti berusaha memenuhi kepuasan diri, kesenangan, fantasi, kepuasan sosial dan emosional. Menurut Park et al., (2006), motivasi belanja hedonis memiliki peran penting dalam pembelian impulsif, karena motivasi belanja hedonis menjadi pendorong konsumen menyukai suatu produk, senang dan juga karena pengaruh emosional.

\section{METODE}

Penelitian dilaksanakan pada bulan Desember 2020. Metode pengumpulan data yaitu dengan metode survey, studi literatur dan kuosioner. Intrumen yang digunakan yaitu kuesioner mengenai flash sale dan implusive buying sebanyak 27 butir pertanyaan yang telah dilakukan uji validitas. penelitian ini menggunakan teknik random sampling. Populasi dalam penelitian ini adalah mahasiswa perempuan di Program Studi Pendidikan Ekonomi total keseluruhan yaitu 347 orang peneliti memilih wanita karena sesuai dengan target pasar market place. Penentuan jumlah sampel pada penelitian ini menurut Arikunto (2010), jika subjeknya kurang dari 100 orang sebaiknya diambil semuanya, jika subjeknya besar atau lebih dari 100 orang dapat diambil $10-15 \%$ atau $20-25 \%$ atau lebih, sehingga jumlah populasi yang ada sebesar 347 digunakan 15 persen 30 dari jumlah populasi diperoleh sebanyak 52 mahasiswa. Dengan demikian jumlah sampel yang digunakan yaitu sebanyak 52 responden. Teknik analisis yang digunakan yaitu regresi linear sederhana dengan penyajian data dalam bentuk tabulasi narasi. 


\section{HASIL DAN DISKUSI}

\section{Pengujian Instrumen}

Intrumen penelitian ini dibuat berdasarkan jumlah variabel dalam penelitian, yaitu sejumlah 2 variabel yang terdiri dari variabel X (flash sale) dan Variabel Y (impulsive buying) dengan jumlah total indikator pernyataan 27 butir dan diuji terhadap 52 responden. Semua intrumen pernyataan dari variabel X yang sudah diisi oleh 52 responden dinyatakan valid karena semua hasil hitung instrumen menunjukkan bahwa $r$ hitung $>$ r tabel yang sebesar 0,138 maka butir pertanyaan valid.

Langkah selanjutnya yang dilakukan setelah uji validitas adalah uji reliabilitas. Suatu instrumen dapat dikatakan reliabel bila memiliki koefisien keandalan reliabilitas sebesar $>0,6$. Jika nilai yang diperoleh dibawah 0,6 maka alat ukur yang dibuat tidak reliabel. Kriteria indeks reliabilitas adalah sebagai berikut dengan nilai tingkat keandalan Alpha Croncbach. Dilihat dari hasil diperoleh bahwa Cronbach's Alpha flash sale sebesar 0.741 dan impulsive buying sebesar 0.641. Dengan demikian bahwa semua intrumen pernyataan dari variabel $\mathrm{X}$ dan variabel $\mathrm{Y}$ dinyatakan Reliabel karena semua hasil hitung instrumen dari masing-masing variabel menunjukkan bahwa hasil hitung Cronbach's Alpha lebih besar semua dari skor minimum yaitu 0,6 .

\section{Uji Asumsi Klasik}

Dari hasil perhitungan menggunakan SPSS didapatkan hasil bahwa data dalam kondisi normal yaitu dengan nilai sig dari dua variabel yaitu sebesar 0,29 $>0,05$. Dari data hasil perhitungan, didapatkan hasil uji linearitas sebesar $0.071>$ dari 0,05 maka dapat disimpulkan bahwa terdapat hubungan yang linear antara variabel flash sale dengan variabel impulsive buying. Uji korelasi digunakan untuk mengukur tingkat keeratan hubungan linear antar dua variabel independen dengan variabel dependen. Uji korelasi dilakukan dengan menggunakan analisis pearson product moment. Dengan menggunakan SPSS 25, ditemukan output pengujian korelasi sebagai berikut:

Tabel 1. Tabel Korelasi

\begin{tabular}{lcr|r}
\hline \multicolumn{4}{c}{ Correlations } \\
\hline & & \multicolumn{1}{c}{$\mathrm{Y}$} \\
\hline Pearson Correlation & $\mathrm{Y}$ & 1.000 & .516 \\
\multirow{2}{*}{ Sig. (1-tailed) } & $\mathrm{X}$ & .516 & 1.000 \\
& $\mathrm{Y}$ &. & .000 \\
$\mathrm{~N}$ & $\mathrm{X}$ & .000 &. \\
& $\mathrm{Y}$ & 54 & 54 \\
& $\mathrm{X}$ & 54 & 54 \\
\hline
\end{tabular}

Sumber: Hasil Olah Data, 2020

Dari Tabel 1 diketahui bahwa terdapat hubungan positif dan signifikan antara Flash Sale dan Impulsive Buying dengan kekuatan hubungan sebesar 0.516. berdasarkan criteria Guilfor, nilai 0.516 berada pada kategori "sedang". Dari hasil tersebut dapat diketahui bahwa apabila flash sale meningkat maka impulsive buying pun akan meningkat, demikian pula sebaliknya. 


\section{Analisis Regresi Linier Sederhana}

Pengujian hipotesis ini dilakukan dengan menggunakan metode analisis regresi linier berganda yang bertujuan untuk menguji hubungan pengaruh antara satu variabel terhadap variabel lain. Pengujian terhadap model penelitian ini untuk mengetahui pengaruh flash sale terhadap impulsive buying. Untuk menentukan persamaan regresi dapat dilihat pada Tabel 2 dibawah ini:

Tabel 2. Koefisien Determinasi

\begin{tabular}{llrrr}
\hline \multicolumn{5}{c}{ Model Summary } \\
\hline Model & $\mathrm{R}$ & $\mathrm{R}$ Square & Adjusted R Square & Std. Error of the Estimate \\
\hline 1 & $.516^{\mathrm{a}}$ & .267 & .253 & 5.41899 \\
\hline
\end{tabular}

a. Predictors: (Constant), $\mathrm{X}$

Sumber: Hasil Olah Data, 2020

Dari tabel di atas, dapat diketahui bahwa koefisien determinasi (Adjusted $R$ Square) sebesar 0.267, hal ini menunjukkan indeks determinasi, yaitu persentase yang menyumbangkan pengaruh flash sale terhadap impulsive buying. Adjusted $R$ Square sebesar 0.267 mengandung pengertian bahwa $26.7 \%$ sumbangan flash sale terhadap impulsive buying, sedangkan sisanya sebesar $73.3 \%$ dipengaruhi oleh faktor lain.

Tabel 3. Tabel Hasil Analisis Regresi Linier Sederhana

\begin{tabular}{|c|c|c|c|c|c|c|}
\hline \multicolumn{7}{|c|}{ Coefficients $^{\mathrm{a}}$} \\
\hline & & $\begin{array}{r}\text { Unsta } \\
\text { Coe }\end{array}$ & $\begin{array}{l}\text { lardized } \\
\text { cients }\end{array}$ & $\begin{array}{c}\text { Standardized } \\
\text { Coefficients }\end{array}$ & & \\
\hline \multicolumn{2}{|c|}{ Model } & $\mathrm{B}$ & Std. Error & Beta & $\mathrm{t}$ & Sig. \\
\hline \multirow[t]{2}{*}{1} & (Constant) & 16.513 & 6.304 & & 2.619 & .012 \\
\hline & $\mathrm{X}$ & .624 & .144 & .516 & 4.349 & .000 \\
\hline
\end{tabular}

a. Dependent Variable: Y

Sumber: Hasil Olah Data, 2020

Berdasarkan tabel diketahui bahwa nilai koefisien dari persamaan regresi dari output didapatkan model persamaan regresi:

$$
\mathrm{Y}=16.513+0.624 \mathrm{x}+\varepsilon
$$

Koefisien regresi yang bertanda positif menunjukkan perubahan yang searah antara variabel bebas terhadap variabel terikat, sedangkan koefisien yang bertanda negatif menunjukkan perubahan yang berlawanan. Berikut merupakan interpretasi dari nilai regresi. Dari hasil uji bivariate hitung di atas dapat diambil kesimpulan bahwa nilai konstanta (a) sebesar 16.513. Hal ini menunjukkan jika seluruh variabel 
bebas yang digunakan tidak mengalami perubahan (konstan), maka impulsive buying akan mengalami kenaikan sebesar 16.513 kali yang disebabkan oleh variabel lain yang tidak digunakan dalam penelitian. Koefisien regresi $B$ untuk variabel flash sale sebesar 0.624. Hal ini menunjukkan jika program flash sale mengalami kenaikan sebesar satu kali, maka impulsive buying akan mengalami peningkatan sebesar 0.624 kali dengan asumsi variabel lainnya konstan (tidak berubah).

Kriteria perhitungan jika t hitung $>$ t tabel, maka Ho ditolak dan Ha diterima, ini berarti hubungan flash sale terhadap impulsive buying signifikan. Apabila $\mathrm{t} t$ hitung < t tabel, maka Ho diterima dan Ha ditolak artinya tidak ada hubungan yang signifikan antara flash sale terhadap impulsive buying. Berdasarkan hasil perhitungan diketahui bahwa nilai t hitung $>\mathrm{t}$ tabel, yaitu $4.349>3,115$ ini berarti Ho ditolak dan Ha diterima. Dengan demikian hipotesis yang diajukan, yaitu terdapat pengaruh flash sale terhadap impulsive buying dapat diterima.

\section{Pembahasan}

Penelitian ini ditujukan untuk mengukur pengaruh flash sale terhadap impulsive buying. Hipotesis yang diajukan dalam penelitian ini yaitu terdapat pengaruh flash sale terhadap perilaku impulse buying pada online shop marketplace. Pembahasan lebih lanjut mengenai penelitian ini, hasil uji korelasi diketahui jika flash sale mempunyai hubungan yang positif dan signifikan dengan impulsive buying dengan kekuatan hubungan tinggi. Demikian juga dengan hasil analisis regresi linier sederhana diketahui jika flash sale memiliki pengaruh terhadap impulsive buying. Pada penelitian ini, menunjukkan respon yang positif dengan kategori tinggi ada pada variabel flash sale dan impulsive buying dengan kontribusinya sebesar $81 \%$.

Penelitian ini sejalan dengan penelitian terdahulunya yang dilakukan oleh Suci Sekar Ayuning tahun 2019 dengan judul Promosi Penjualan dan Impulse Buying yang terletak di tingkat kontribusi promosi penjualan terhadap impulsive buying yang cukup tinggi yaitu hanya 68\%. Pada dimensi indikator dari flash sale yang terdapat pada 3 indikator variabel yang pertama yaitu hubungan dimensi pengurangan harga terhadap dimensi, spontanity, power, compulsion, intensity, excitement memiliki hubungan sedang. Hal ini senada dengan yang diungkapkan juga oleh Shoham \& Brencic dalam Ria Arifianti dalam Prihastama (2016) mengatakan bahwa impulse buying berkaitan dengan perilaku untuk membeli berdasarkan emosi.

Sedangkan dimensi pengurangan harga terhadap dimensi stimulation dan disregard for consequences memiliki hubungan kuat. Temuan tersebut didukung oleh Mowen \& Minor dalam Prihastama (2016) yang mendefinisi pembelian impulsif (impulse buying) adalah tindakan membeli yang dilakukan tanpa memiliki masalah sebelumnya atau maksud/niat membeli yang terbentuk sebelum memasuki toko. Sedangkan menurut Schiffman dan Kanuk dalam Prihastama (2016) impulse buying merupakan keputusan yang emosional atau menurut desakan hati.

Hasil penelitian ini sesuai dengan temuan Kannan dan kawan-kawan bahwa aktivitas media sosial dan promosi flash sales mampu meningkatkan penjualan setelah produk diluncurkan. Yang artinya saat flash sales banyak terjadi pembelian yang dilakukan konsumen. Hal tersebut didukung oleh teori yang di kemukakan oleh Kotler dan Keller, yang menjelaskan bahwa promosi penjualan terdiri dari kumpulan alat-alat insentif yang beragam, sebagian besar berjangka pendek, dirancang untuk mendorong pembelian suatu produk atau jasa tertentu secara lebih cepat dan lebih besar oleh konsumen atau pedagang. 
Flash sale merupakan penawaran produk dengan potongan harga dan kuantitas yang terbatas dalam waktu singkat. Flash sale atau yang juga disebut "daily deal", bagian dari promosi penjualan yang memberi pelanggannya penawaran khusus atau diskon untuk produk tertentu untuk waktu yang terbatas. Studi yang dilakukan Agrawal, S. dan Abhinav S. S. (2016) menunjukkan bahwa flash sale telah membantu perusahaan untuk menarik perhatian massa atau calon konsumen.

Menurut Dhurup (2014) belanja juga muncul sebagai kegiatan sosial, hiburan dan liburan, sehingga pembelian yang direncanakan secara kognitif mulai berkurang, mengakibatkan muncul anggapan bahwa fenomena melakukan pembelian secara impulsif merupakan hal yang umum dan dapat diterima secara sosial di negara maju dan berkembang.

Belanja dengan harga diskon mudah ditemui di Indonesia. Diskon seakan menjadi daya tarik utama untuk menrik minat masyarakat memberli suatu barang. Potongan harga adalah pengurangan harga produk dari harga normal dalam periode tertentu. Berdasarkan pada hasil penelitian dan pembahasan menunjukkan bahwa terdapat pengaruh flash sale terhadap impulsif buying di marketplace.

\section{KESIMPULAN}

Penelitian yang dilakukan kepada mahasiswa Program Studi Pendidikan Ekonomi, dan menghasilkan kesimpulan bahwa flash sale memberikan pengaruh signifikan terhadap impulsive buying. Berdasarkan pada 3 dimensi flash sale dan 7 dimensi impulsive buying diperoleh bahwa pada dimensi pengurangan harga terhadap dimensi, spontanity, power, compulsion, intensity, excitement memiliki hubungan sedang. Sedangkan dimensi pengurangan harga terhadap dimensi stimulation dan disregard for consequences memiliki hubungan kuat. Selanjutnya pada dimensi ketepatan program pengurangan harga terhadap spontaneity, power, compulsion adalah sedang, excitement, stimulation adalah sedang, disregard for consequences memiliki hubungan sedang hubungan ketepatan program pengurangan harga dengan intensity adalah kuat. Sedangkan pada dimensi Frekuensi Program Potongan Harga terhadap Power, compulsion, intensity, excitement, stimulation, dan disregard for consequences memiliki hubungan sedang dan hubungan antara frekuensi program potongan harga dengan spontanity memiliki hubungan yang kuat.

\section{DAFTAR PUSTAKA}

Agrawal, S. dan Abhinav S. S. 2016. Flash Sales-The Game Changer in Indian ECommerce Industry". International Journal of Advance Research and Innovation, 4(1), 192-195.

Arikunto. 2010. Suharsimi Arikunto.pdf. In Prosedur Penelitian Suatu Pendekatan Praktik-Revisi ke $X$.

Banks, J., Blundell, R., \& Lewbel, A. 1997. Quadratic Engel Curves snd Consumer Demand. Review of Economics and Statistics. https://doi.org/10.1162/003465397557015

Chaffey, D., \& Bosomworth, D. 2013. Digital marketing strategy planning template. Smart Insights. 
Dhurup, M. 2014. Impulsive Fashion Apparel Consumption: The Role of Hedonism, Fashion Involvement and Emotional Gratification in Fashion Apparel Impulsive Buying Behaviour in a Developing Country. Mediterranean Journal of Social Sciences. https://doi.org/10.5901/mjss.2014.v5n8p168

Lokadata. 2019. Jumlah investor pasar modal Indonesia, 2012-Agustus 2019. Lokadata.

Park, E. J., Kim, E. Y., \& Forney, J. C. 2006. A structural Model of Fashion-Oriented Impulse Buying Behavior. Journal of Fashion Marketing and Management. https://doi.org/10.1108/13612020610701965

Peck, J., \& Childers, T. L. 2006. If I Touch it I Have to hHave it: Individual and Environmental Influences on Impulse Purchasing. Journal of Business Research. https://doi.org/10.1016/j.jbusres.2006.01.014

Kotler, P., \& Keller, K. L. 2016. Marketing Management. Global Edition (Vol. 15E). https://doi.org/10.1080/08911760903022556eting Management. In Global Edition.

Prihastama. 2016. Pengaruh Price Discount dan Bonus Pack terhadap Keputusan Impulse Buying pada Pt. Toyota Auto 2000 Cabang Sisingamangraja Medan Nasi. Journal of Business Studies.

Turban, E., King, D., Lee, J. K., Liang, T.-P., \& Turban, D. 2012. Electronic Commerce: a Managerial and Social Networks Perspective 2012. In Commerce A Managerial Perspective (5th ed.) 